\title{
GIS-BASED APPROACH TO ESTIMATE SURFACE RUNOFF IN SMALL CATCHMENTS: A CASE STUDY
}

\author{
Matej VojteK, Jana Vojteková \\ Department of Geography and Regional Development, Constantine the Philosopher University in Nitra, Slovakia
}

Manuscript received: April 24, 2016

Revised version: August 13, 2016

\begin{abstract}
Vojтек M., VojтекоVÁ J., 2016. GIS-based approach to estimate surface runoff in small catchments: a case study. Quaestiones Geographicae 35(3), Bogucki Wydawnictwo Naukowe, Poznań, pp. 97-116, 12 figs, 1 table.

AвSTRACT: The issue of surface runoff assessment is one of the important and relevant topics of hydrological as well as geographical research. The aim of the paper is therefore to estimate and assess surface runoff on the example of Vyčoma catchment which is located in the Western Slovakia. For this purpose, SCS runoff curve number method, modeling in GIS and remote sensing were used. An important task was the creation of a digital elevation model (DEM), which enters the surface runoff modeling and affects its accuracy. Great attention was paid to the spatial interpretation of land use categories applying aerial imagery from 2013 and hydrological soil groups as well as calculation of maximum daily rainfall with $\mathrm{N}$-year return periods as partial tasks in estimating surface runoff. From the methodological point of view, the importance of the paper can be seen in the use of a simple GIS-based approach to assess the surface runoff conditions in a small catchment.
\end{abstract}

KEY WORDS: surface runoff, GIS, SCS runoff curve number method, land use, small catchment

Corresponding author: Matej Vojtek (e-mail:mvojtek@ukf.sk)

\section{Introduction}

Estimation and assessment of surface runoff is an important and relevant issue of hydrological as well as geographical research. Surface runoff is a significant factor affecting the development and progress of floods, soil erosion, and other hydrological hazards.

One of the methods for its determination is the SCS-CN runoff curve number method. This method was developed by the Natural Resources Conservation Service, which was formerly called the Soil Conservation Service (SCS) coming under the U.S. Department of Agriculture (USDA) (Mishra, Singh 2003). Several studies were written aiming at finding a theoretical basis for the method and supporting its further improvement (Hjelmfelt 1991, Yu 1998).

According to Soulix, Valiantzas (2011), the SCS-CN method evolved also beyond its original scope and it became an integral part of simulation models (e.g. Mishra, Singh 2004, Zhan, Huang 2004, Soulis, Dercas 2007, Moretti, Montanari 2008, Adornado, Yoshida 2010). Geographic Information Systems (GIS) has been extensively used in these models especially for the tasks of data preparation, model parameter extraction or model results visualization.

On the other hand, the catchment hydrologic responses leading to generation of surface runoff are governed by the interaction of precipitation with topological, land use and soil properties. 
Therefore, use of GIS is preferred over the traditional techniques in proper quantification of surface runoff (Patil et al. 2008). Moreover, the estimation process becomes more efficient and interactive when solely GIS is used for storing, analyzing, interpreting, and displaying the data required in $\mathrm{CN}$ based runoff estimation techniques.

The SCS-CN method was used for various regions having different landscape structure (land use), soils and climate conditions (Wilcox et al. 1990, Holman et al. 2003, Romero et al. 2007, Tedela et al. 2012, Nagarajan, Basil 2014). Based on their results, the SCS-CN runoff method is recommended to be used in relatively small catchments as an alternative to rainfall-runoff models or in order to create a basic idea of the rainfall-runoff conditions in a certain area.

Knowledge of changes in the surface runoff conditions requires an analysis of land use. In recent decades, there have been intensifying anthropogenic impacts on the landscape which are caused by the agriculture, forestry, water management modifications, architectural-technical and industrial activities, tourism, etc. The consequences of these activities are reflected in the change of runoff conditions, deforestation, accelerated soil erosion, disruption of hydrologic regime of landscape, surface recreation, and land cover or land use change (Oláhová et al. 2013).

Landscape structure or land use determines, in particular, the hydrological transformation of rainfall in the catchment. The impact of current land use on hydrological transformation can be divided into two basic groups.

The first group is represented by the impact caused by direct application of land use in rainfall-runoff relations while the processes such as interception and evapotranspiration are applied. The second important group of influence is the function of land use as a protective factor of soils where in its horizons, a substantial part of the transformation of stormwater to runoff is being carried out. Changes in the structure of vegetation (spatial or generic) or direct deforestation may initiate a short-term response of the catchment (dynamics and parameters of the individual rainfall-runoff episodes) as well as a longterm response (e.g. changes in specific or basic runoff).
The way of creating land use maps is currently allowed by the progress of geoinformation technologies such as remote sensing and GIS. Mainly the remote sensing methods allow rapid collection of information on the current landscape in corresponding precision and quality. Its final products - orthophotos can be used to obtain up to date information on the landscape, but also to reconstruct its conditions in the past based of which it is possible to define the degree of anthropogenic influence (Munteanu et al. 2014).

The aim of the paper is to introduce a simple GIS-based method to assess surface runoff characteristics such as depth or volume on the example of a small catchment using the SCS-CN method and recorded rainfall data, modeling in GIS and remote sensing.

\section{Study area}

The study area is represented by the Vyčoma catchment which is located in the Nitra River Basin. The geographical coordinates of the catchment are $48^{\circ} 35^{\prime} \mathrm{N}, 48^{\circ} 29^{\prime} \mathrm{N}$ latitude and $18^{\circ} 12^{\prime} \mathrm{E}$, $18^{\circ} 26^{\prime} \mathrm{E}$ longitude. The total catchment area is $99.94 \mathrm{~km}^{2}$. The Vyčoma watercourse forms a left tributary of the Nitra River with the length of 25.2 $\mathrm{km}$. It springs in the Tribec mountain beneath the Vel'ký Vravcov peak (609 m a.s.1.) (Fig. 1).

The catchment is a part of two geomorphological units - Podunajská pahorkatina (hills) and Tribeč (mountain) (Dubcová et al. 2008). The highest point has an elevation of $715 \mathrm{~m}$ a.s.l. and it is located beneath the Javorový vrch peak (730 $\mathrm{m}$ a.s.l.) in the southern part of the catchment. The lowest point is located at an elevation of 168 $\mathrm{m}$ a.s.l. where the Vyčoma watercourse flows into the Nitra River.

Podunajská pahorkatina (hills) extends into the catchment with its sub-units - Nitrianska pahorkatina (hills) and Nitrianska niva (plain). This area is dominated by slightly wavy and plain relief formed by Pleistocene loess. The geological composition of the Tribeč mountain is varied. Its basis is formed by schist with series consisting of quartzite, limestone, and dolomite. Particularly, positions of quartzites, conglomerates, and sandstones are morphologically very strongly manifested. In the Rázdiel sub-unit, also granitoids or Mesozoic rhyolites and dacite volcanic rocks 


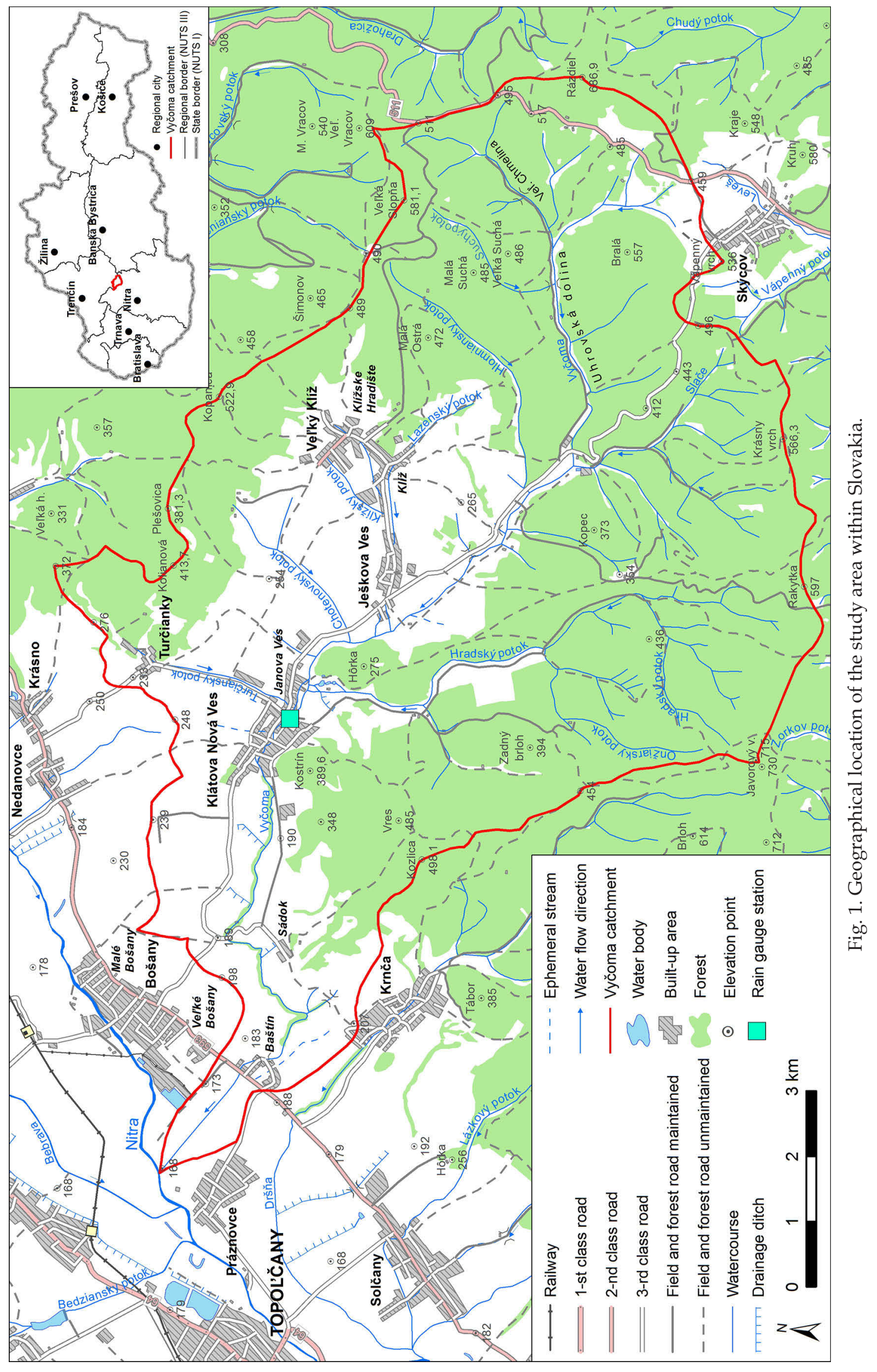


can be found there. In the Vel'ký Tribeč sub-unit, there are also positions of hybrid granodiorites and tonalites (Ivanička et al. 1998).

The study area lies in the temperate climate zone. Average annual rainfall represents 600-700 $\mathrm{mm} /$ year and towards the mountains rises to 800 $\mathrm{mm}$ /year (Lapin et al. 2002).

From the administrative point of view, the catchment belongs to the Western Slovakia (NUTS II), Trenčín Region (NUTS III), and Partizánske District (NUTS IV). The following municipalities are located in the catchment: Vel'ký Klíž, Ješkova Ves, Klátova Nová Ves, Turčianky.

\section{Data and methods}

Given the aim of the paper, the methods used required the application of different data and specialized software.

\section{Digital elevation model (DEM)}

The basis for the creation of DEM was represented by 13 maps of the Basic Map of the Slovak Republic in a raster format at a scale of $1: 10000$ with the contour interval of 2 and $5 \mathrm{~m}$. In order to convert the raster format of maps to the vector format, ArcScan extension within ArcGIS Desktop 10.1 software was used. The vector files, in particular, contours and elevation points were crucial for interpolation and consisted of 2,257 contour lines and 258 elevation points. From the hydrological point of view, the vector files of watercourses and water bodies were also used to create the DEM.

To calculate the DEM, the interpolation method of Topo to Raster was used, which is a specific method designed for creating hydrologically correct DEMs (Hutchinson 1988). The choice of optimal spatial resolution is an important task which depends mainly on the scale and use of DEM. Hengl (2006) recommends to choose the size of the pixel between the mean and lowest value of contours distance which was in this case $13.70 \mathrm{~m}$ and $2.65 \mathrm{~m}$. According to Šúri et al. (2003), the spatial resolution can range from 1 to $5 \mathrm{~m}$ for applications at large scales (up to $1: 10$ 000). Based on the aforementioned, the resulting raster has the cell size of $5 \times 5 \mathrm{~m}$ (Fig. 2).

\section{Land use}

One of the sources for the interpretation of land use in the Vyčoma catchment was the Basic Map of the Slovak Republic at a scale of $1: 10000$. Since the basic topographic maps can already be outdated, the current state of land use was identified by using orthophotos from 2013 in TIFF format with the resolution of $20 \times 20 \mathrm{~cm} /$ pixel which were provided by the company GEODETICCA, s.r.o. As a result, six categories of land use were identified and subsequently digitized in ArcGIS Desktop 10.1 software by using the visual "on screen" method, where the land use patches were digitized directly on the computer screen. The results of the land use interpretation are presented on Fig. 3.

\section{Soils}

Information on soils in the study area were obtained from the maps of soil types which were provided by the Soil Science and Conservation Research Institute (VÚPOP), Bratislava and National Forest Centre (NLC), Zvolen. Based on the underlying data, five soil types were identified (Fig. 4).

The predominant are medium sandy-loam soils which occur mainly at higher elevations of forested areas where they bind to granodiorites, granites, gneisses, mica schists, sandstones and thus the geological bedrock of the Tribeč (mountain). In addition, sandy-loam soils at lower altitudes bind to the Tertiary gravels and sands.

Light loamy-sand soils occur in the form of differently sized islets that interrupt mainly continuous areas of sandy-loam soils. They bind in particular to slacks of quartzites, quartz sandstones, and rhyolites.

At lower elevations, medium loam soils are dominant. They bind especially to the Tertiary and Quaternary sediments of the Nitrianska pahorkatina (hills).

Moreover, heavy clay-loam soils are also represented in the catchment. They can be found in the Nitrianska pahorkatina (hills) where they bind to the granularly heavier sediments, loess loams, loess or Neogene sediments. In the Tribeč (mountain), they bind mainly to the geological bedrock formed by limestones, dolomites, and shales. Heavy clay soils are less represented in the study area. 


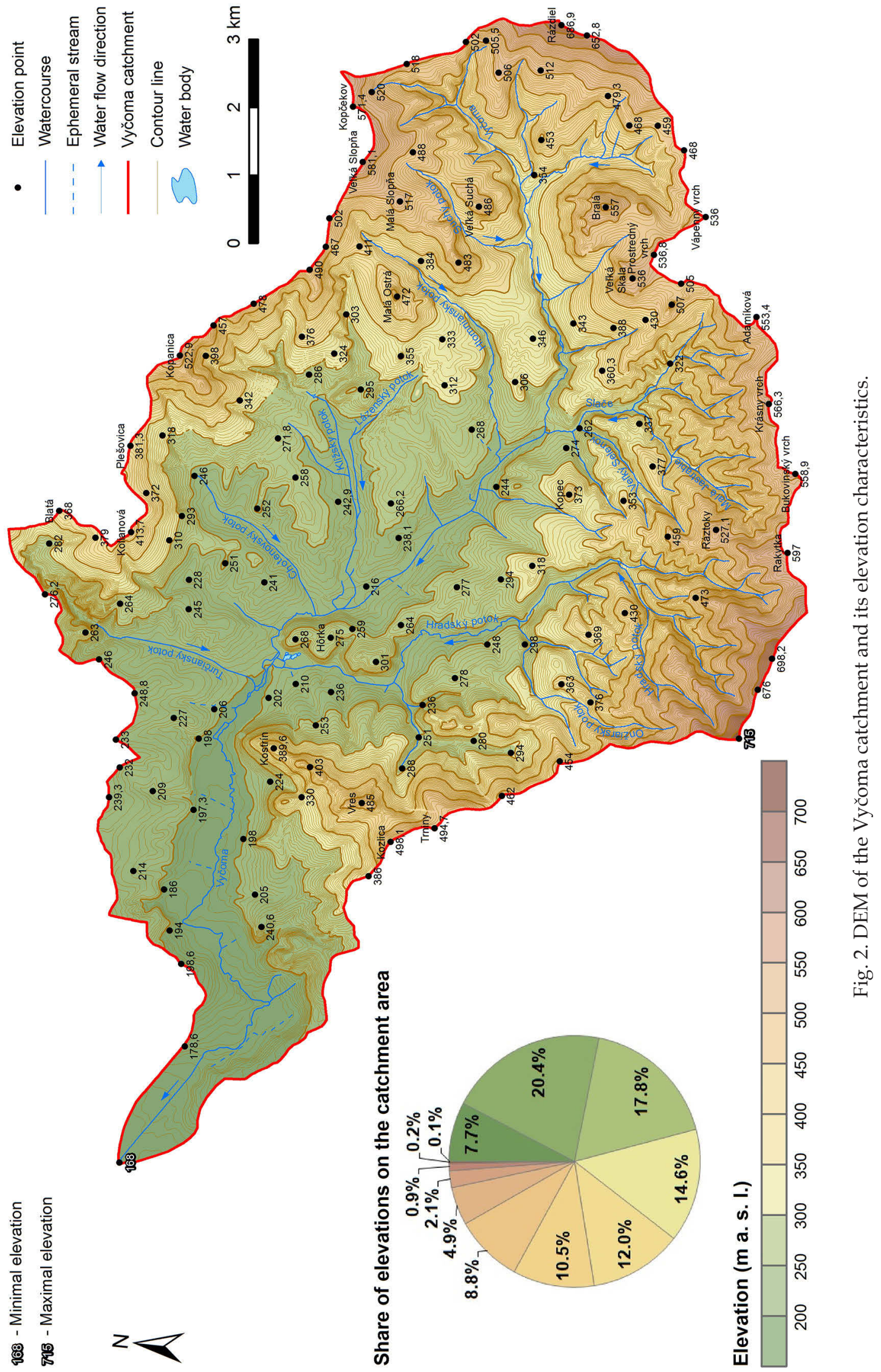




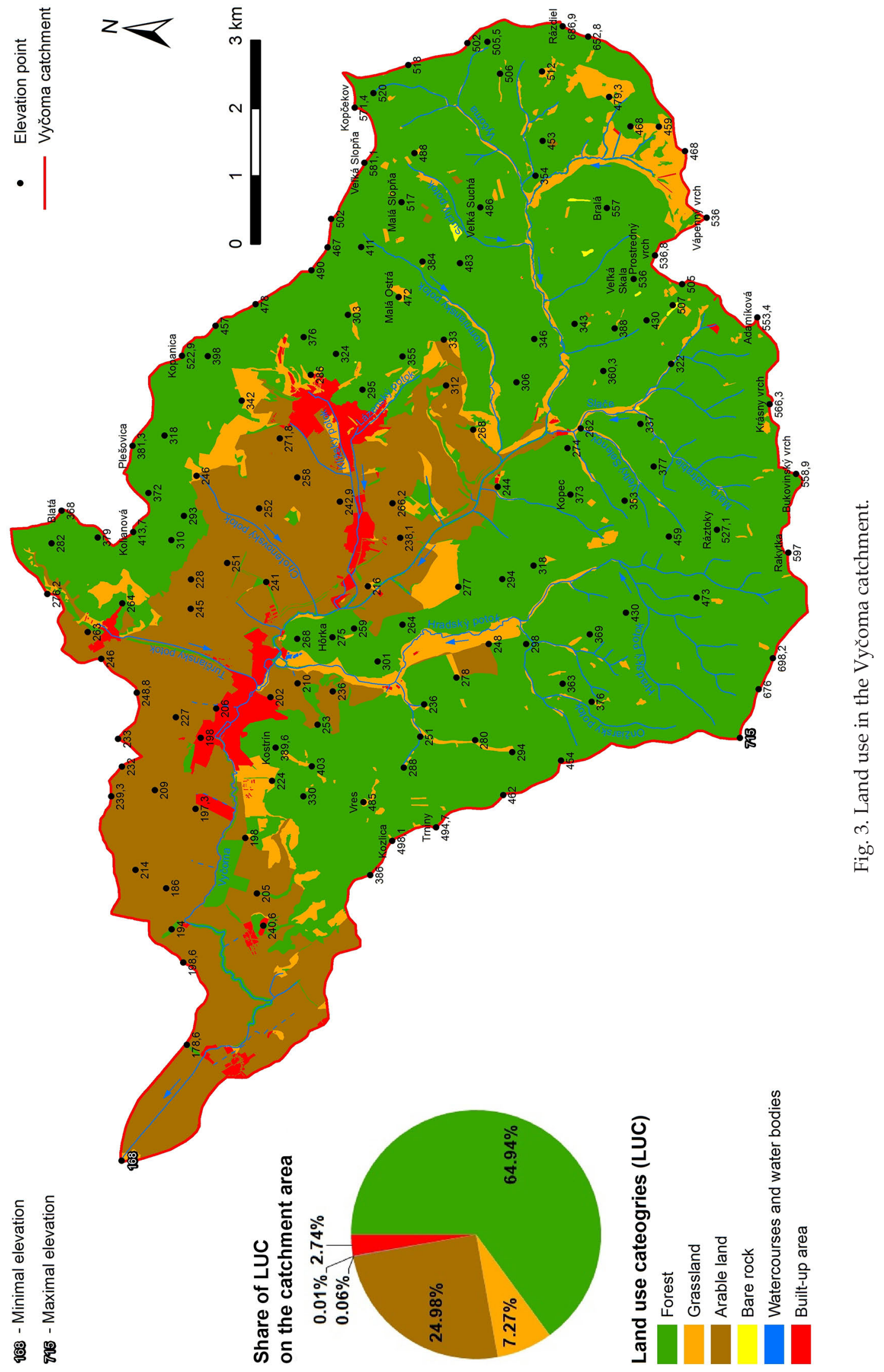




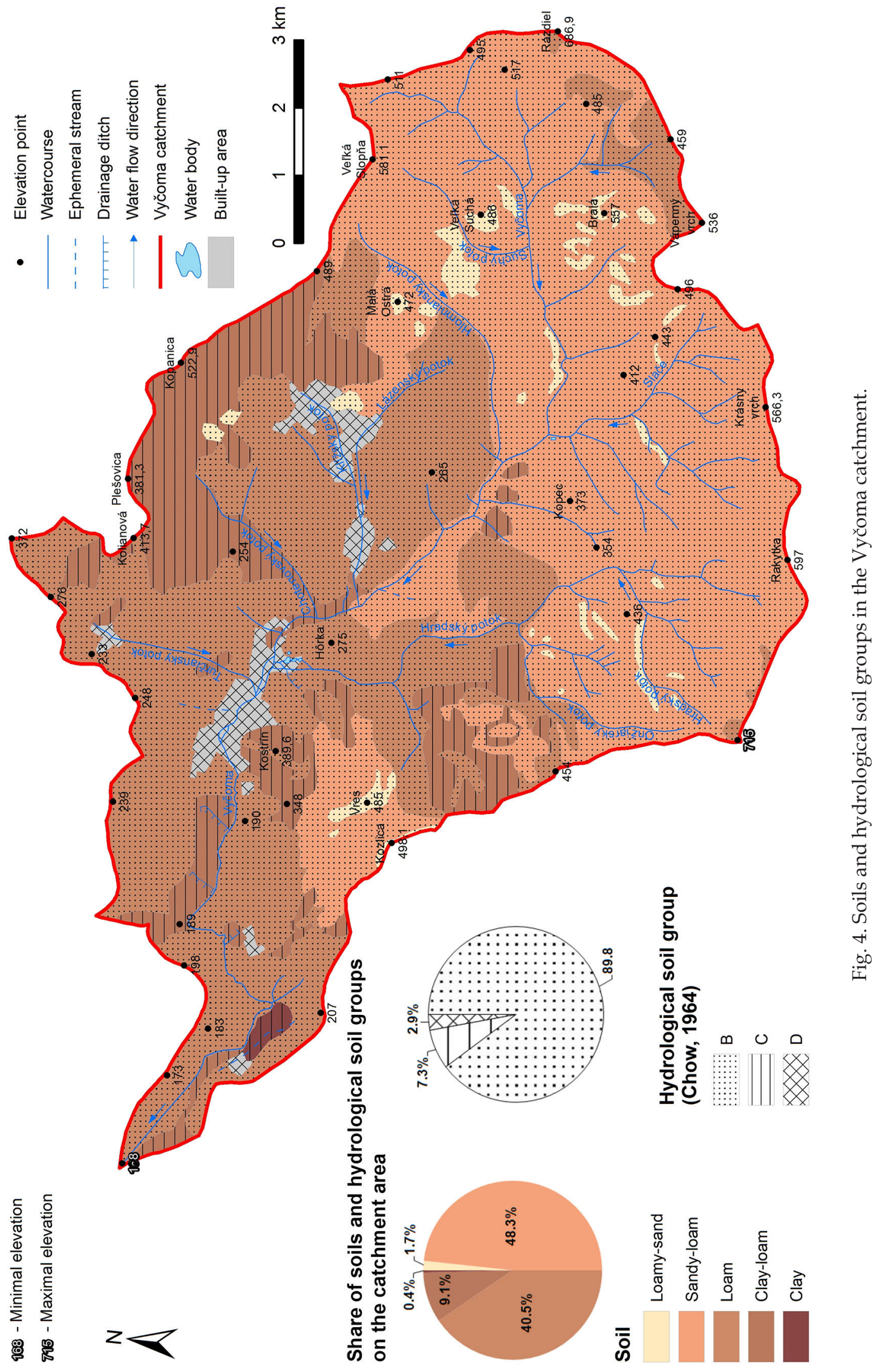


Depending on the infiltration and drainage characteristics of soils, they can be generally divide into four hydrological soil groups according to Chow (1964). However, there is a number of direct and indirect effects that affect the infiltration capacity of soils.

Based on the map of soil types, three hydrological soil groups were identified in the Vyčoma catchment (Fig. 4): B - Soils having moderate infiltration rates when thoroughly wetted and a moderate rate of water transmission and $\mathrm{C}$ - Soils having low infiltration rates when thoroughly wetted and a low rate of water transmission. Group D - Soils having very low infiltration rates when thoroughly wetted and a very low rate of water transmission was assigned to the soils in the built-up areas.

\section{Estimation of maximum daily rainfall}

To determine the maximum daily rainfall with different $\mathrm{N}$-year return periods, a set of measured peak rainfall for 32 years (1981-2012) from the Klátova Nová Ves rain gauge station was used - geographical coordinates: $48^{\circ} 33^{\prime} 41^{\prime \prime} \mathrm{N}$ latitude, $18^{\circ} 18^{\prime} 44^{\prime \prime} \mathrm{E}$ longitude; elevation: 195 $\mathrm{m}$ a.s.l. (Fig. 1). Three theoretical curves were constructed using Pearson type III distribution, log-normal distribution, and Gumbel distribution. The method of moments and quantiles were used to estimate their parameters.

The calculated values of probability of theoretical curves of exceedence and their corresponding maximum daily rainfall are provided on Fig. 5. These curves were compared with the empirical curve of exceedence. Based on this comparison, we determined the optimal concord between empirical and theoretical probability curve of exceedence and also the most suitable theoretical distribution for the determination of $\mathrm{N}$-year maximum daily rainfall from a given set of values. In our case, the most suitable theoretical curve appears to be the log-normal distribution using the method of moments which best balances the empirical curve of maximum daily rainfall.

\section{SCS-CN method and surface runoff calculation}

In order to determine the curve numbers, it was necessary to know the following:

- hydrological soil groups in the catchment (Fig. 4),

- hydrological characteristics of the soil moisture conditions which are expressed by the Antecedent Moisture Condition (AMC),

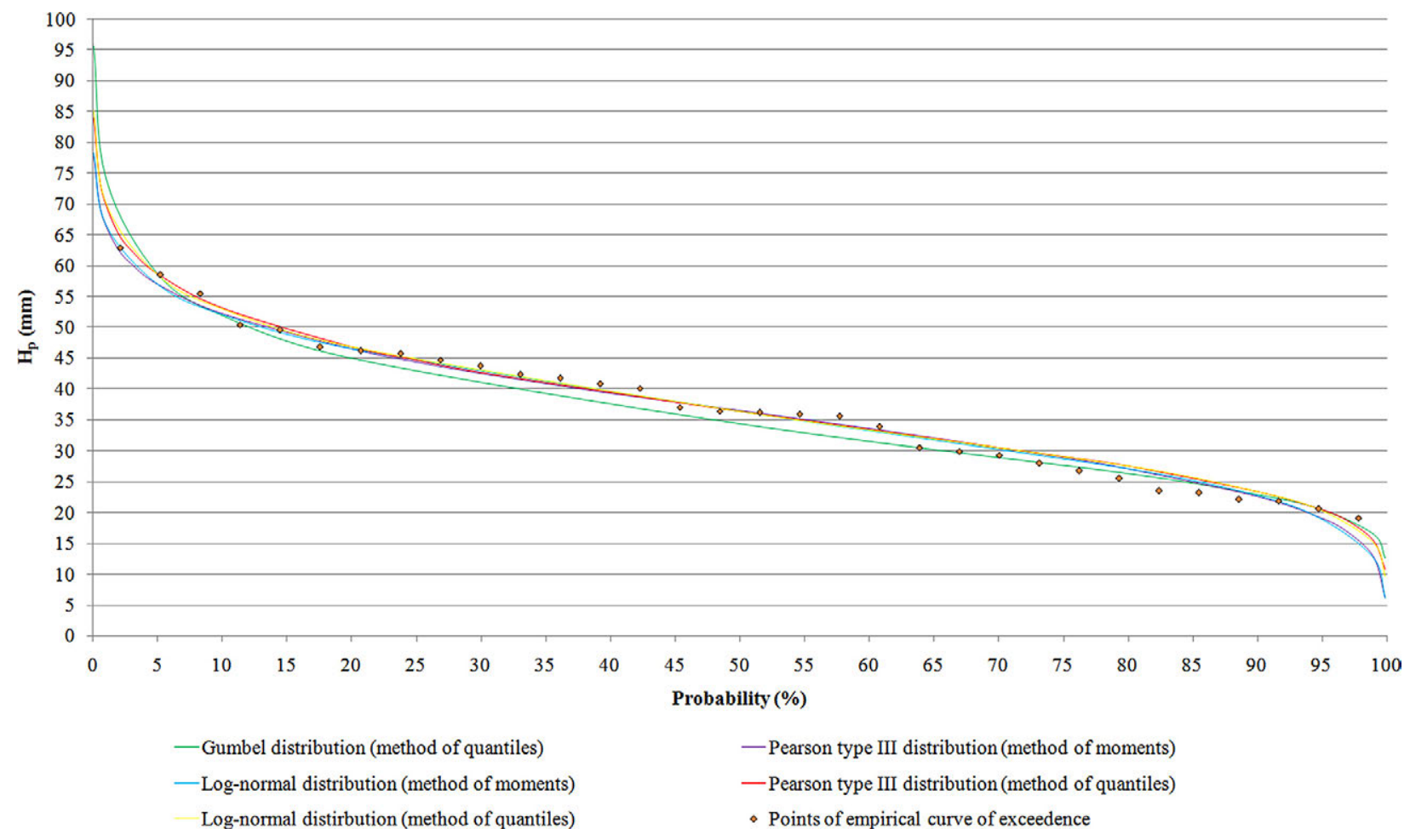

Fig. 5. Comparison of empirical and theoretical curves of exceedence in the Klátova Nová Ves rain gauge station. 
- hydrological characteristics of the land use categories in the catchment with their respective curve numbers.

As for the soil moisture conditions, they are based on the Antecedent Moisture Condition (AMC) index which refers to antecedent moisture content in the soil 5 days prior to the beginning of the rainfall-runoff event under consideration (Chow 1964, Chow et al. 1988). In our case, the AMC III and average conditions were took into account since only the highest 1-day rainfall in the period of 1981-2012 represents $63 \mathrm{~mm}$ (Fig. 5).

With the use of SCS-CN table (Chow 1964, McCuen 1982, Cronshey et al. 1986, Chow et al. 1988) and based on the map of hydrological soil groups and map of land use categories, the resulting curve numbers were obtained (Table 1). Using the extension of HEC-GeoHMS for ArcGIS Desktop 10 (US Army Corps of Engineers 2002), the $\mathrm{CN}$ grid was created defining areas with different curve numbers in the Vyčoma catchment.

After the creation of $\mathrm{CN}$ grid, the extension of Hydrotools 1.0 for ArcView GIS 3.2 (Schäuble 2003) was used in order to create the raster of representative curve numbers which conditions the creation of averaged data that subsequently enter further partial calculations of surface runoff. Alternatively, it is possible to use the combination of Hydrology tools and Raster Calculator tool which are incorporated in newer versions of ArcGIS software. In order to simplify the SCS$\mathrm{CN}$ method and get the averaged data, the values of curve numbers were recalculated to representative values by using the weighted average in relation to the contributing area of the discharge profile. In GIS, however, each pixel represents a discharge profile. The raster of representative curve numbers is thus a result of the division of accumulation raster, where the raster of curve

Table 1. Curve numbers for land use categories

\begin{tabular}{|l|r|r|c|}
\hline \multirow{2}{*}{\multicolumn{1}{|c|}{ Land use category }} & \multicolumn{3}{c|}{$\begin{array}{c}\text { Hydrological soil } \\
\text { group }\end{array}$} \\
\cline { 2 - 4 } & \multicolumn{1}{|c|}{ B } & \multicolumn{1}{c|}{ C } & D \\
\hline Forest & 60 & 73 & 79 \\
\hline Grassland & 58 & 71 & 78 \\
\hline Arable land & 72 & 81 & 86 \\
\hline Bare rock & 85 & 89 & - \\
\hline Watercourses and water bodies & 100 & 100 & 100 \\
\hline Built-up area & 77 & 83 & 87 \\
\hline
\end{tabular}

numbers was used as a weight, and the accumulation raster without weight Equation (1):

Representative $\mathrm{CN}$ values $=$ accumulation raster; weight: raster of $\mathrm{CN}$ values accumulation raster; without weight

The calculation of surface runoff is based on the potential retention in the catchment. Generally, surface runoff occurs after a certain loss which is the sum of interception, surface retention, and infiltration. The size of this loss (initial abstraction) was estimated on the basis of experimental measurements to $20 \%$ of the potential retention $\left(\mathrm{I}_{\mathrm{a}}=\right.$ 0.2A) (Cronshey et al. 1986). Potential retention capacity $(A)$ of the catchment was then calculated using the values of representative curve numbers (Equation 2):

$$
A=25.4\left(\frac{1000}{C N_{\text {rep }}}-10\right)
$$

The runoff depth was calculated using Equation (3) (Cronshey et al. 1986):

$$
H_{o}=\frac{\left(H_{p}-0.2 A\right)^{2}}{H_{p}+0.8 A}
$$

In addition to the potential retention of catchment $(A)$, the formula contains also the value of maximum daily rainfall with $\mathrm{N}$-year return period $\left(H_{p}\right)$. In our case, we chose the maximum daily rainfall with 100-year return period which was calculated based on the log-normal distribution and method of moments $(66.53 \mathrm{~mm})$.

The next step was to create a raster of contributing areas $\left(S_{p}\right)$ in the catchment where each cell is inserted the number of connected cells in the direction of flow above this cell and their size is then calculated. Equation (4) was used for the calculation of contributing areas $\left(S_{p}\right)$ where the cell size has a value of $25 \mathrm{~m}^{2}$ :

$S_{p}=$ accumulation raster $\times$ cell size / 1000000.

The volume of surface runoff was calculated based on Equation (5) where $H_{o}$ is depth of surface runoff and $S_{p}$ represents contributing areas:

$$
O_{p}=H_{o} \times S_{p} \times 1000 \text {. }
$$




\section{Results}

By applying the described methods, surface runoff characteristics were spatially modeled within the Vyčoma catchment.

The basic parameter for surface runoff modeling is flow accumulation. The raster of surface runoff accumulation is derived from the flow direction raster while each cell is determined the number of cells that flow into it which means that each cell is also the discharge profile (Fig. 6). Theoretically, if each cell is multiplied with the rainfall which would fell on it, the total volume of water in the final discharge profile could be subtracted from the raster. However, this would be a theoretical approach which does not consider the possibility of evaporation or infiltration. Therefore, the SCS-CN method was applied.

\section{Curve numbers}

The curve numbers were classified into four classes (Fig. 7). The highest runoff potential is represented by 90-100 class which, however, covers only $0.01 \mathrm{~km}^{2}$ whereas 58-60 class of curve numbers occupies $61.56 \mathrm{~km}^{2}$ of the total area having the lowest runoff potential. The $61-80$ curve number class, which is low moderate runoff potential, covers $31.88 \mathrm{~km}^{2}$ while the moderate runoff potential (81-89 class) occupies only $6.49 \mathrm{~km}^{2}$. These values were then recalculated using accumulation raster to averaged representative $\mathrm{CN}$ values (Fig. 8).

\section{Surface runoff depth and volume}

In terms of the potential retention, the values range from 0 to $183.9 \mathrm{~mm}$ (Fig. 9). The smaller the value of the potential retention the higher the curve number and vice versa. The most vulnerable are built-up areas in the catchment, where the retention capacity is low. Similarly, agricultural land which is located near the municipalities has a poorer retention capacity as long as it is being improperly used. Particularly, it is from these areas where the surface runoff is being increased and accelerated and then concentrated in streams flowing through built-up areas.

The resulting raster of runoff depth is shown on Fig. 10 where the values range from 4.1 to $66.5 \mathrm{~mm}$ depending on the retention capacity of individual surfaces. The lowest values occur in the southern and southeastern part of the study area which is caused on one hand, by the high potential of water interception by the forest coverage and on the other hand, by water retention due to predominantly sandy-loam soil texture. As long as these areas represent more than $50 \%$ of the total catchment area, the risk of surface runoff is thus decreased. The most exposed to surface runoff are built-up areas or river valleys, where the $\mathrm{CN}$ number frequently exceeds the value of 81 . The Vyčoma catchment contains also areas which are vulnerable to the occurrence of floods and they mostly correspond with the areas of high depth of surface runoff. These include, for example, the lower part of the Klížsky potok (stream), confluence of Hradský potok (stream) and Vyčoma (stream) or Vyčoma (stream) in the built-up area of the Klátova Nová Ves municipality where several flood events have already occurred (Fig. 10).

Another runoff characteristics is represented by the contributing areas. The resulting raster was in $\mathrm{km}^{2}$, however, it was converted to $\mathrm{m}^{2}$ for better understanding (Fig. 11). This indicator affects the calculated volume of surface runoff which provides the information on volume of runoff $\left(\mathrm{m}^{3}\right)$ in each cell which would be formed on the surface of this cell (Fig. 12).

\section{Discussion}

With regard to the results and methods used, there are possible sources of uncertainty and improvements which should be considered and discussed.

The role of DEM and its quality is crucial for the results of surface runoff modeling. When using large-scale maps (in our case $1: 10$ 000) to create DEM, it is necessary to take into account their generalization. On the other hand, such representation of relief may have better quality as compared to DEMs derived from satellite images with lower resolution such as ASTER GDEM, SRTM, LANDSAT or IFSAR. The most suitable would be to use photogrammetrical or LIDAR data which are more accurate. However, it was not financially possible in our case. For that reason, the optimal choice was to use the most accurate topographic map and create correct input data for the DEM. 

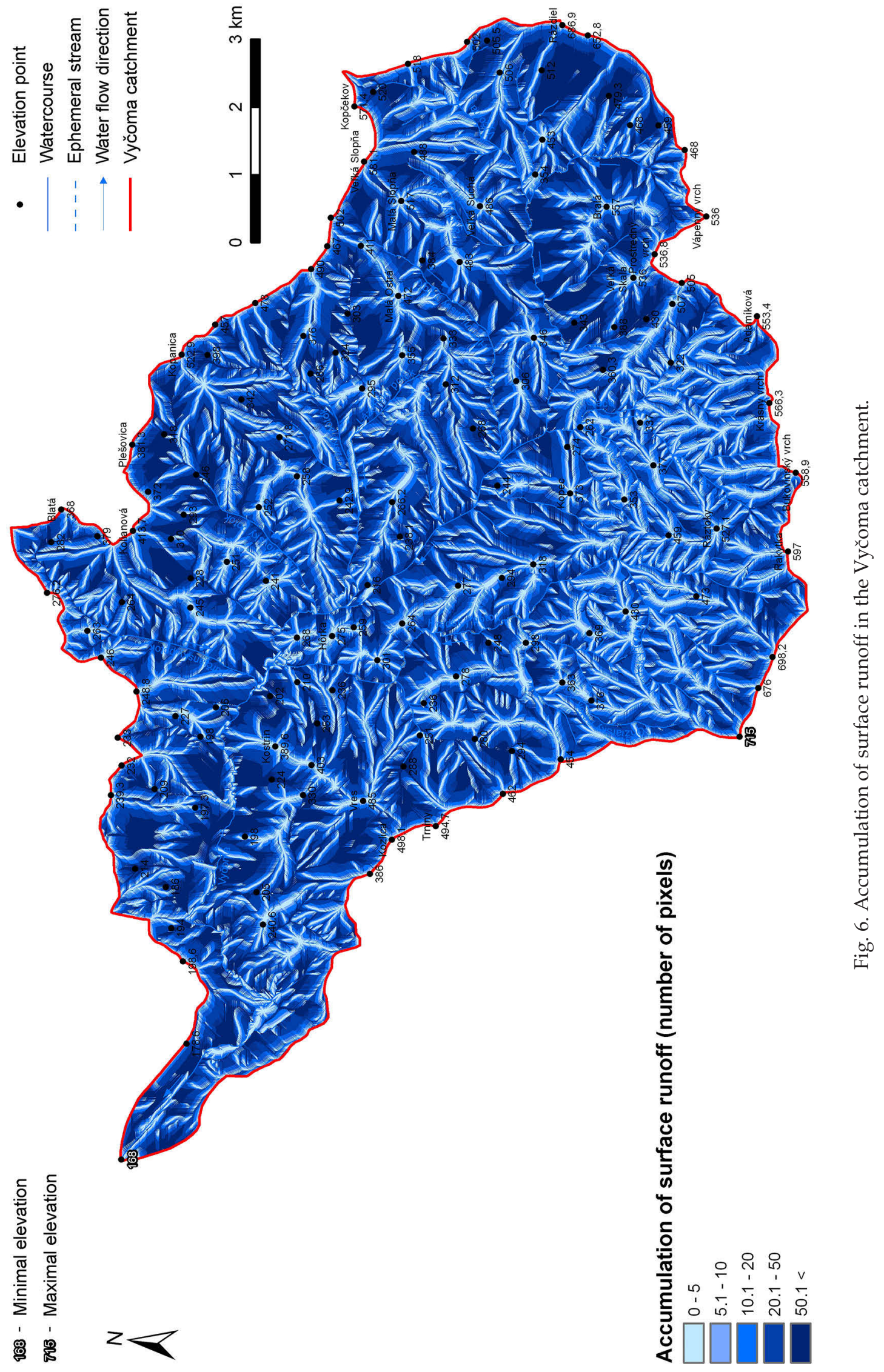


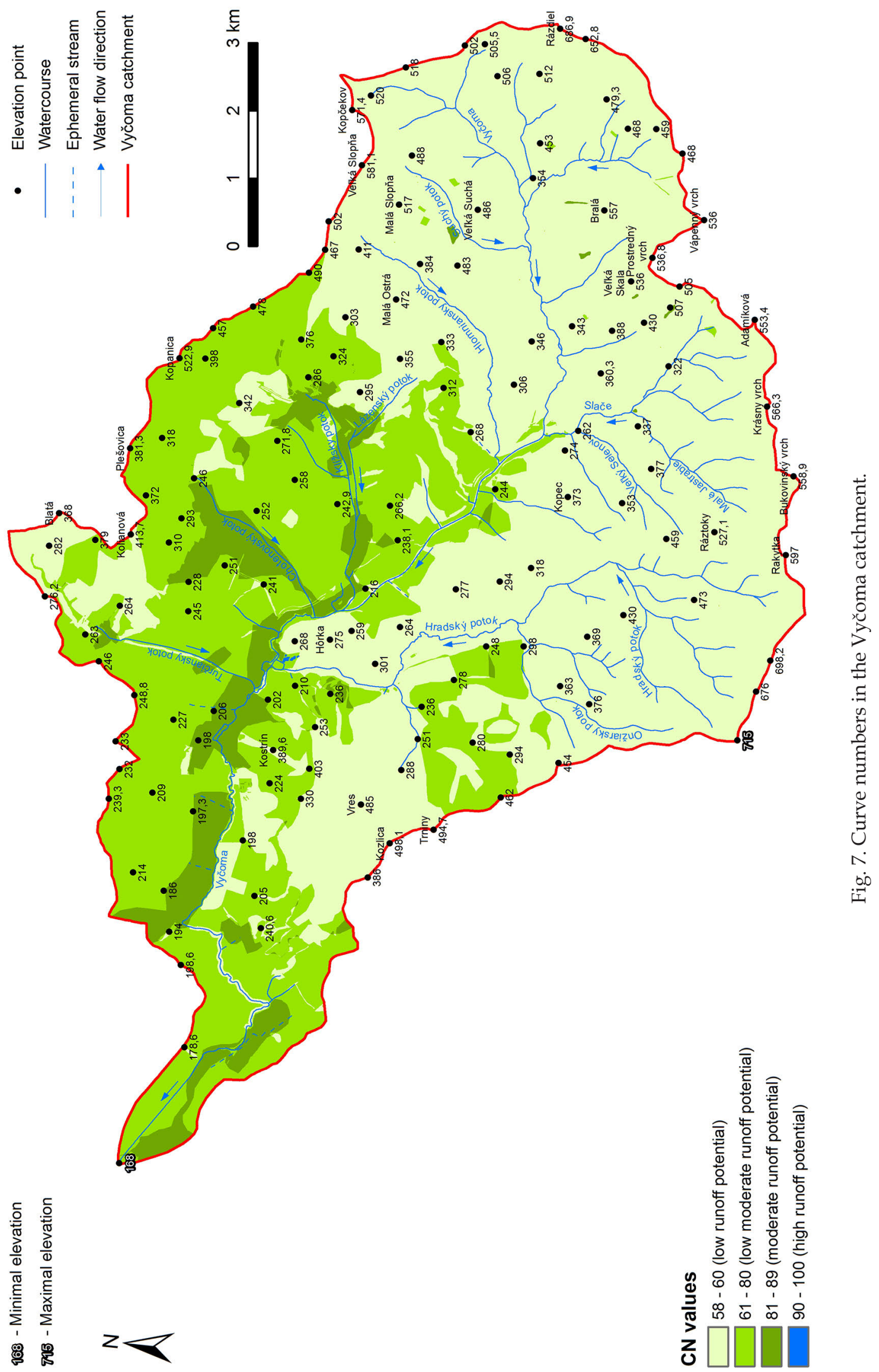



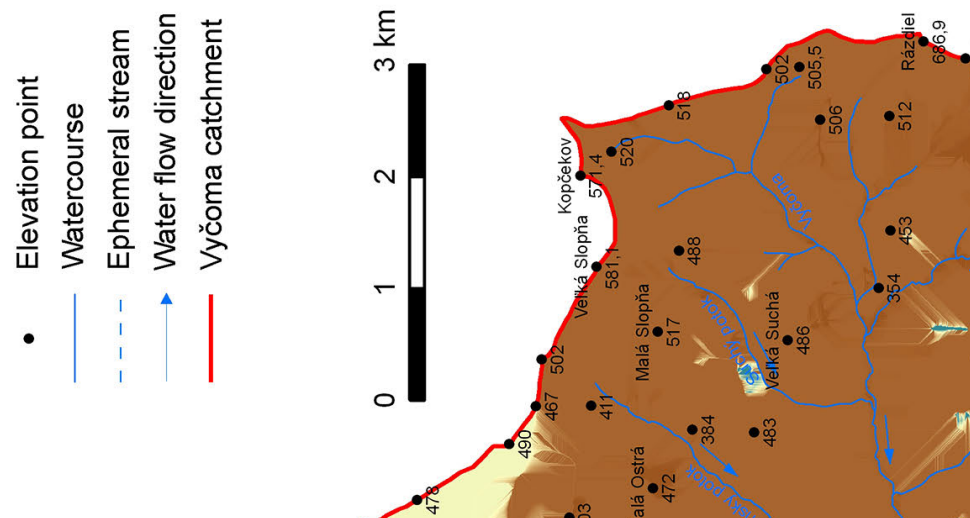


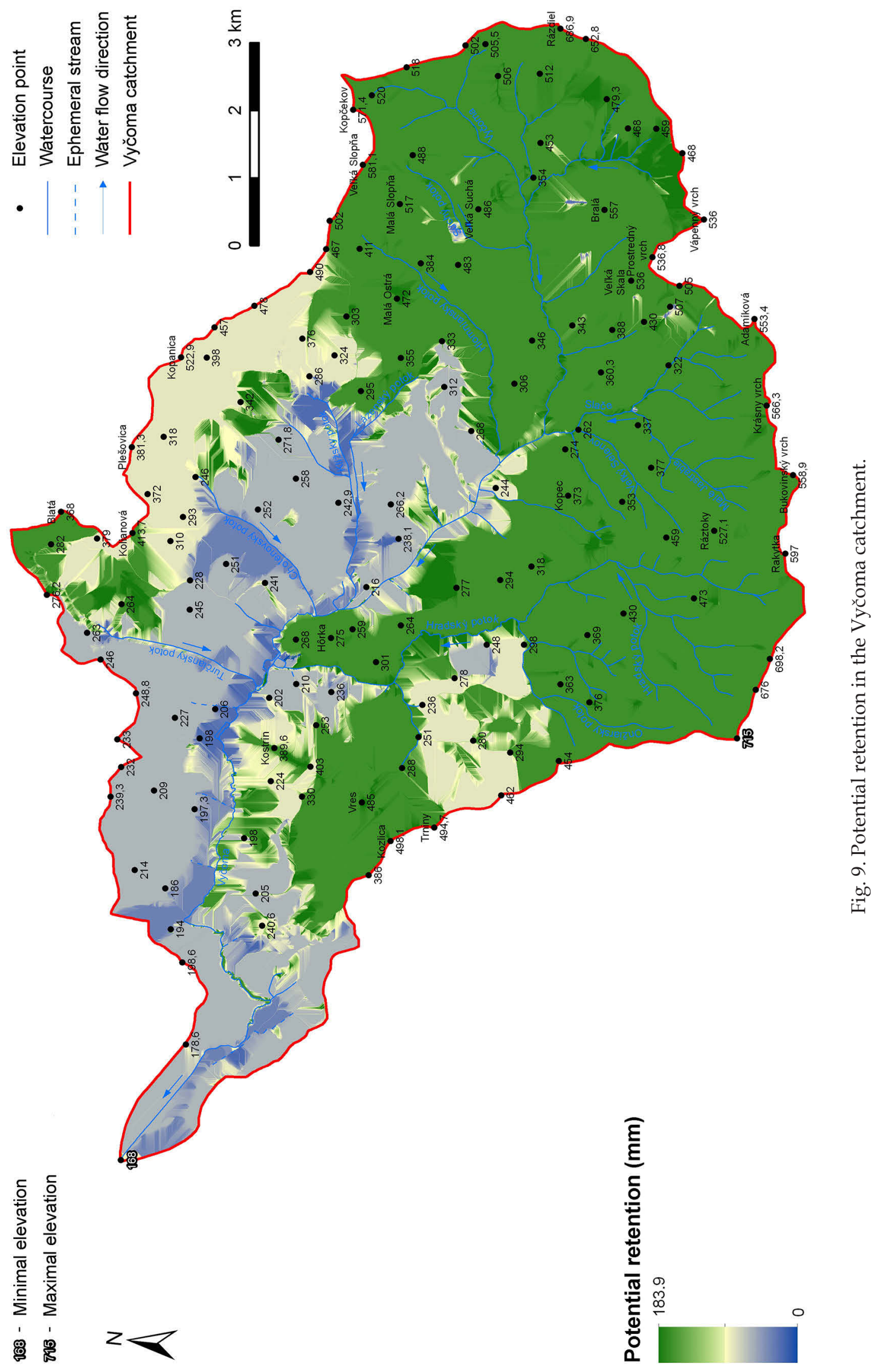



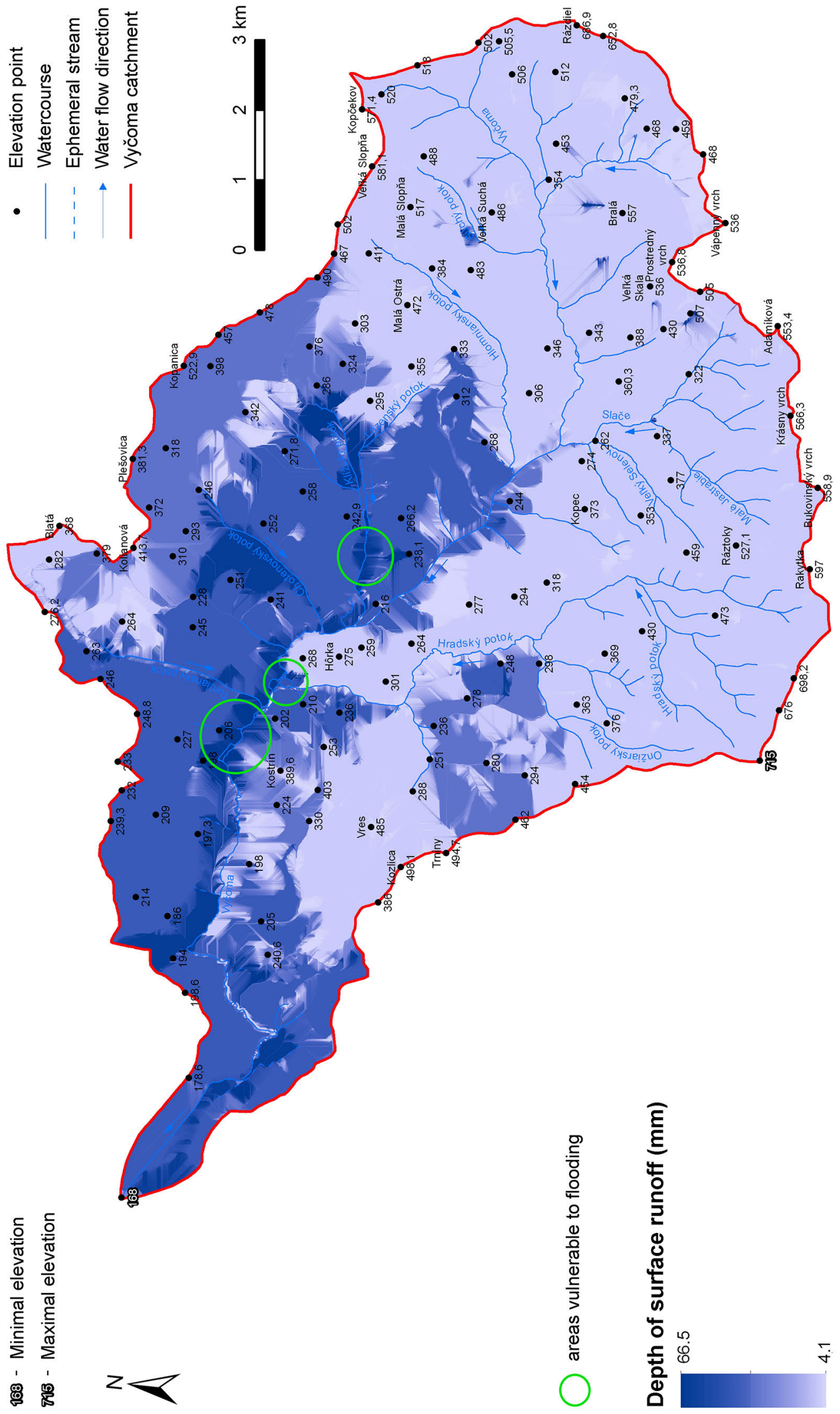

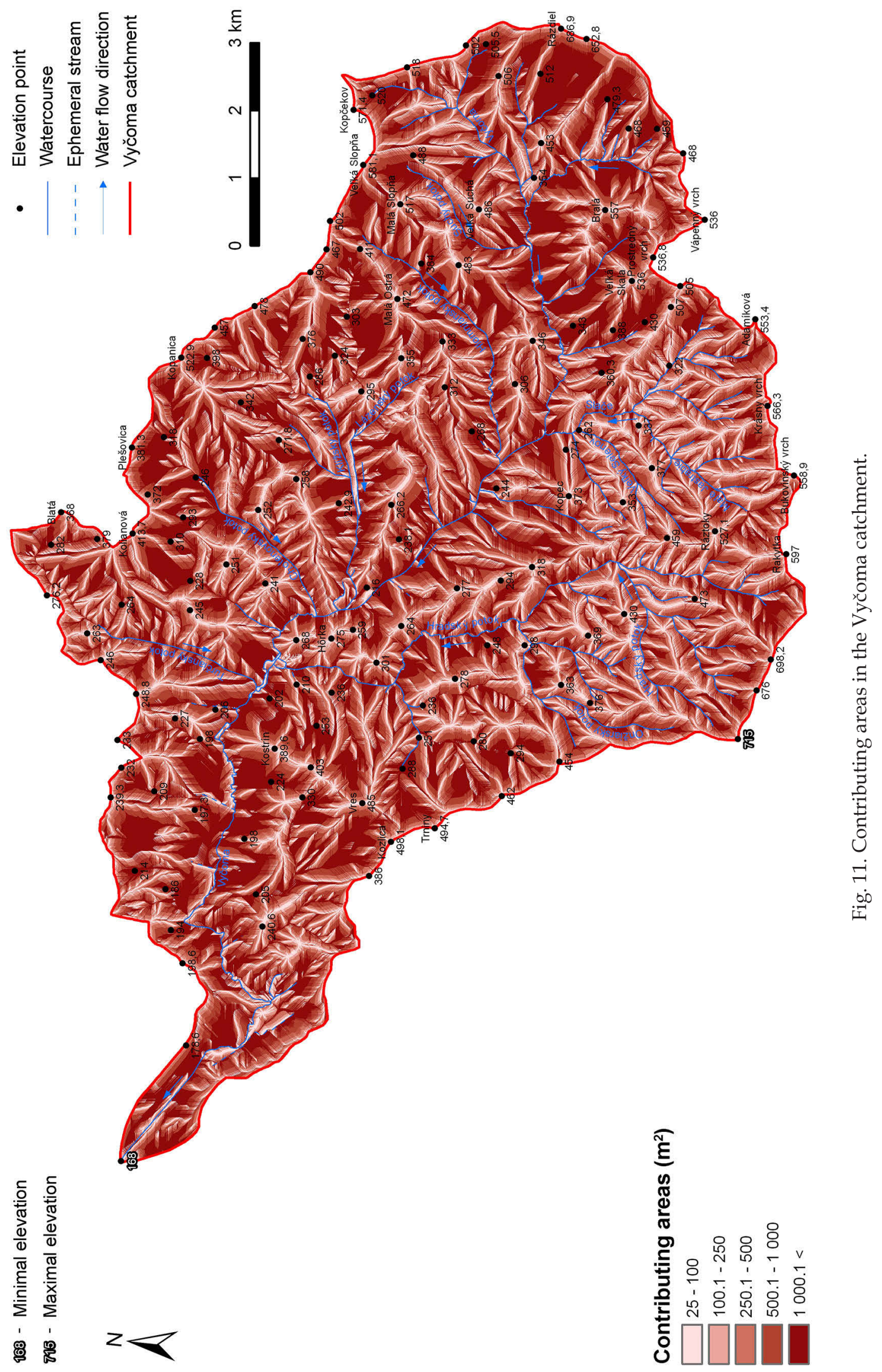

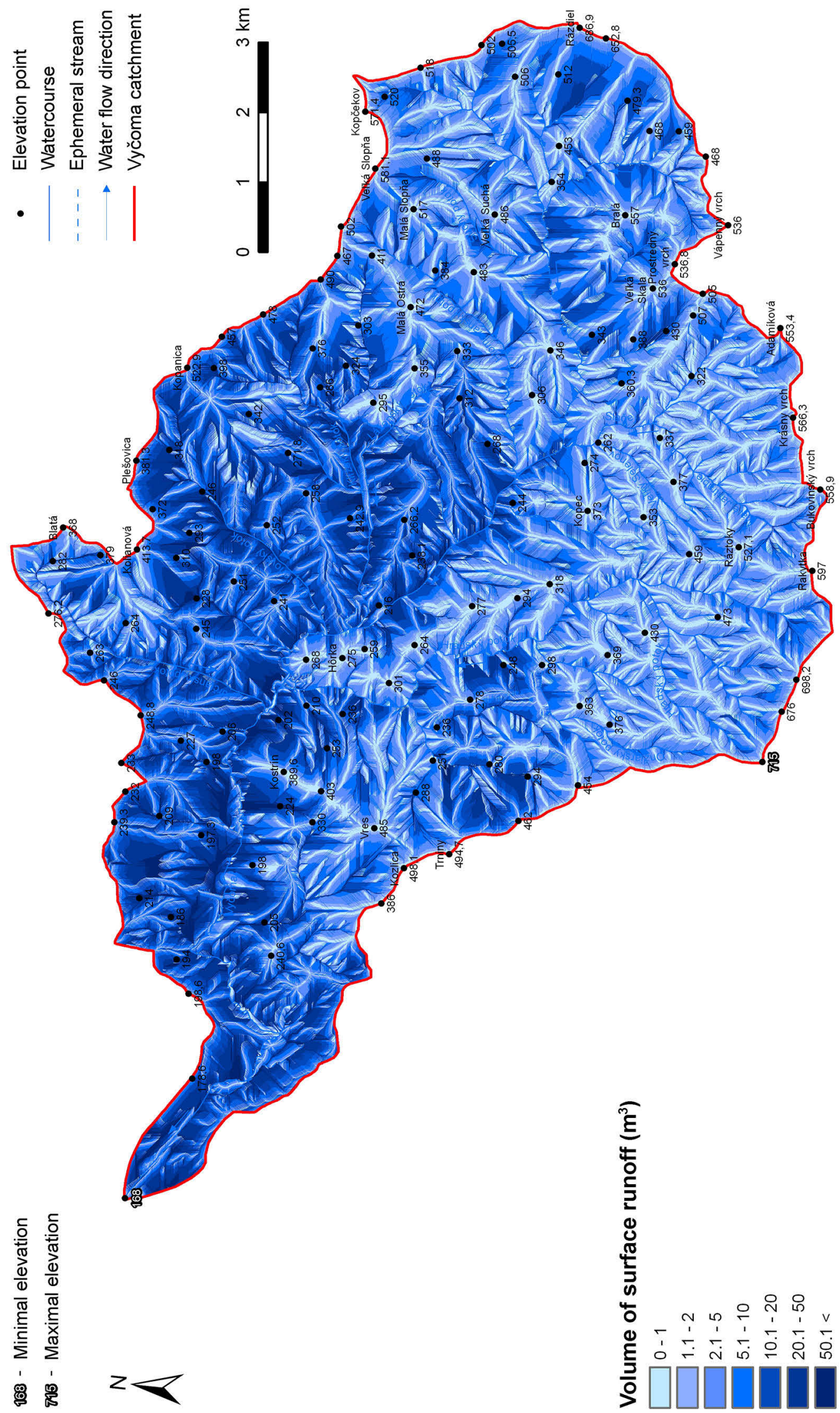
As for the interpolation method used, Topo to Raster method (Hutchinson 1988) allows creating hydrologically correct DEM since it takes into account the river network or water bodies. It is a modification of spline method which, according to Desmet (1997), showed the best results when comparing several interpolation methods for DEM creation. Another advantage of gridbased DEMs is the possibility to use map algebra for further terrain and surface runoff analyses.

When estimating maximum daily rainfall with $\mathrm{N}$-year return period by direct methods, we meet with several uncertainties. The first uncertainty arises from the quality of underlying data (i.e. direct observations). The observations of peak rainfall for 32 years at the Klátova Nová Ves rain gauge station were used. According to Makel et al. (2003), this set should be uninterrupted (homogeneous) and longer than 20 years which in our case meets this requirement. On the other hand, a reliable estimation of 100-year rainfall in a particular rain gauge station would require 500 -year long observation series which is not recorded by any station in Slovakia (Solín 2005).

The use of statistical methods brings the statistical uncertainty which arises from their substance. This is particularly the choice of theoretical curve, method for parameters estimation, length of set, deviation of estimations from short sets of observations, etc. For that reason, we used several types of distributions and methods for estimating their parameters which enable to choose the theoretical probability curve which best balances the empirical curve. A similar approach was applied by Mitková et al. (2004) who point to the fact that the choice of method and its subsequent statistical analysis has a significant effect on the resulting values of estimations.

It is obvious that the estimation of maximum daily rainfall cannot be considered unambiguous calculation procedure with a clear outcome. It is a task that can be solved by using several statistical methods. In terms of practical usability, the results of different estimations using various methods could be, in principle, considered equivalent if conditions of proper use of each method were fulfilled. As a consequence, this means that the resulting $\mathrm{N}$-year quantity has to be chosen from a range of results of used approaches, which may also be significantly different (Vojtek 2014).
Furthermore, a question may arise regarding the use of rainfall-runoff models as a better option for surface runoff modeling. However, several similar studies e.g. Patil et al. (2008), Agarwal et al. (2013), Costache et al. (2014) or Nagarajan, Basil (2014) suggest that the use of physically based models (e.g. HBV, TOPMODEL or MIKESHE) has a certain disadvantage that they require a large number of input parameters to calibrate them making these models expensive and time consuming. On the contrary, the approach presented in this study provides rather a simpler method to assess surface runoff characteristics based on GIS tools and remote sensing.

\section{Conclusion}

Overall assessment of physical-geographical factors affecting the runoff in the Vyčoma catchment shows that particularly catchment shape, high density of river network, steep slopes, short slope drains as well as geological bedrock form, in spite of the high share of forests, a rapid concentration of surface runoff from the catchment especially after its previous saturation.

The CN method, applied by HEC-GeoHMS extension for ArcGIS 10, showed its efficiency for the presented study as the computation and spatial modeling of the surface runoff managed to reveal the most vulnerable areas, where the exposure to hydrological risks is enhanced by the high surface runoff depth.

Since it is the small catchment, the formation and progress of runoff is significantly affected by the way the landscape is used. The positive impact on the retention of water in the landscape is made by the forests, non-forest woody vegetation and permanent grasslands (mainly meadow vegetation) which cover more than $70 \%$ of the total area. Conversely, a strong negative impact on the runoff and consequently on flood situation is made by impervious parts of residential areas and also agricultural lands when being improperly cultivated.

Based on the results of surface runoff assessment in the studied catchment, it is obvious that GIS-based method has proven to be a suitable tool for the definition of risk areas for potential flood occurrence which is induced by the design rainfall. Analyses of surface runoff conditions 
confirmed the fact that the attention should be mainly paid on the protection of built-up areas which are most vulnerable in terms of flood damages and also human lives may be at risk.

The results of this paper can be applied especially in the areas of flood risk management, urban or landscape planning. The presented results can be also useful for identifying suitable locations for polders or small retention areas using geoinformation technologies so as to reduce the high surface runoff and avoid floods in the study area. However, the main importance of the paper can be seen in the methods used which can be replicable in other similar small catchments.

\section{Acknowledgements}

This work was supported by the University Grant Agency (UGA) of Constantine the Philosopher University in Nitra under Grant no. VIII/35/2015.

\section{References}

Adornado H.A., Yoshida M., 2010. GIS-based watershed analysis and surface run-off estimation using curve number $(\mathrm{CN})$ value. Journal of Environmental Hydrology 18: $1-10$.

Agarwal R., Garg P.K., Garg R.D., 2013. Remote Sensing and GIS Based Approach for Identification of Artificial Recharge Sites. Water Resources Management 27: 2671-2689.

Chow V.T., 1964. Handbook of Applied Hydrology. McGrawHill Book Company, New York.

Chow V.T., Maidment D.R., Mays L.W., 1988. A text book of applied hydrology. Tata McGraw Hill publications, New Delhi.

Costache R., Fontanine I., Corodescu E., 2014. Assessment of surface runoff depth changes in Sărătel River basin, Romania using GIS techniques. Central European Journal of Geosciences 6: 363-372.

Cronshey R., McCuen R.H., Miller N., Rawls W., Robbins S., Woodward D., 1986. Urban Hydrology for Small Watersheds (TR-55). Natural Resources Conservation Service, Washington

Desmet P.J.J., 1997. Effects of Interpolation Errors on the Analysis of DEMs. Earth Surface Processes and Landforms 22: 563-580.

Dubcová A., Lauko V., Tolmáči L., Cimra J., Kramáreková H., Krogmann A., Nemčíková M., Némethová J., Oremusová D., Gurňák D., Križan F., 2008. Geografia Slovenska (Geography of Slovakia). Univerzita Konštantína Filozofa v Nitre, Nitra.

Hengl T., 2006. Finding the right pixel. Computers $\mathcal{E}$ Geosciences 32: 1283-1298.

Hjelmfelt A.T. Jr., 1991. Investigation of curve number procedure. Journal of Hydraulic Engineering (ASCE) 117: 725737.
Holman I.P., Hollis J.M., Bramley M.E., Thompson T.R.E., 2003. The contribution of soil structural degradation to catchment flooding: a preliminary investigation of the 2000 floods in England and Wales. Hydrology and Earth System Sciences 7: 755-766.

Hutchinson M.F., 1988. Calculation of hydrologically sound digital elevation models. In: Third International Symposium on Spatial Data Handling. International Geographical Union, Sydney: 117-133.

Ivanička J., Polák M., Hók J., Határ J., Greguš J., Vozár J., Nagy A., Fordinál K., Pristaš J., Konečný V., Šimon L., 1998. Geologická mapa Tribeča $1: 50000$ (Geological map of Tribeč 1 : 50 000). Geologická služba SR, Bratislava.

Lapin M., Faško P., Melo M., Št'astný P., Tomlain J., 2002. Klimatické oblasti 1 : 1000 000. Atlas krajiny Slovenskej republiky (Climate areas 1:1000 000. Landscape Atlas of the Slovak Republic). MŽP SR, Bratislava, SAŽP, Banská Bystrica.

Makel' M., Turbek J., Podolinská J., Škoda P., 2003. Stanovenie $N$-ročných prietokov a N-ročných prietokových vín na väčších tokoch (Odvetvová technická norma MŽP SR 3112-1:03) (Determination of $\mathrm{N}$-year discharges and $\mathrm{N}$-year discharge waves at greater watercourses (Technical standard of the Ministry of Environment of the Slovak Republic 3112-1:03)).

McCuen R.H., 1982. A Guide to Hydrologic Analysis Using SCS Methods. Prentice-Hall, New Jersey.

Mishra S.K., Singh V.P., 2003. Soil Conservation Service Curve Number (SCS-CN) Methodology. Kluwer Academic Publishers, Dodrecht.

Mishra S.K., Singh V.P., 2004. Long-term hydrological simulation based on the soil conservation service curve number. Hydrological Processes 18: 1291-1313.

Mitková V., Kohnová S., Pekárová P., 2004. Porovnanie odhadov maximálnych sezónnych prietokov $\mathrm{v}$ profile Dunaj - Bratislava (Comparison of the estimates of seasonal maximum discharges on Danube River in Bratislava). Acta Hydrologica Slovaca 5: 34-41.

Moretti G., Montanari A., 2008. Inferring the flood frequency distribution for an ungauged basin using a spatially distributed rainfall-runoff model. Hydrology and Earth System Sciences 12: 1141-1152.

Munteanu C., Kuemmerle T., Boltižiar M., Butsic V., Gimmi U., Halada L., Kaim D., Király G., Konkoly-Gyuró É., Kozak J., Lieskovský J., Mojses M., Müller D., Ostafin K., Ostapowicz K., Shandra O., Štych P., Walker S., Radeloff V.C., 2014. Forest and agricultural land change in the Carpathian region-A meta-analysis of long-term patterns and drivers of change. Land Use Policy 38: 685-697.

Nagarajan M., Basil G., 2014. Remote sensing- and GIS-based runoff modeling with the effect of land-use changes (a case study of Cochin corporation). Natural Hazards 73: 2023-2039.

Oláhová J., Vojtek M., Boltižiar M., 2013. Application of Geoinformation Technologies for the Assessment of Landscape Structure Using Landscape-Ecological Indexes (Case Study of the Handlová Landslide). Tájökológiai Lapok 11: 351-366.

Patil J.P., Sarangi A., Singh O.P., Singh A.K., Ahmad T., 2008. Development of a GIS Interface for Estimation of Runoff from Watersheds. Water Resources Management 22: 1221-1239.

Romero P., Castro G., Gomez J.A., Fereres E., 2007. Curve number values for olive orchards under different soil management. Soil Science Society of America Journal 71: 1758-1769. 
Schäuble H., 2003. HydroTools 1.0 for ArcView 3.x (terracs.de; accessed: 12 August 2016).

Solín L'., 2005. Povodne - odhad ich vel'kosti pre malé povodia Slovenska metódou regionálnej frekvenčnej analýzy (Floods: size estimates for small basins of Slovakia by the method of regional frequency analysis). Geografický časopis 57: 287-307.

Soulis K.X., Dercas N., 2007. Development of a GIS-based spatially distributed continuous hydrological model and its first application. Water International 32: 177-192.

Soulis K.X., Valiantzas J.D., 2011. SCS-CN parameter determination using rainfall-runoff data in heterogeneous watersheds. The two-CN system approach. Hydrology and Earth System Sciences Discussions 8: 8963-9004.

Šúri M., Cebecauer T., Hofierka J., 2003. Digitálne modely reliéfu a ich aplikácie v životnom prostredí (Digital terrain models and their environmental applications). Životné prostredie 37 : $30-35$.

Tedela N.H., McCutcheon S.C., Rasmussen T.C., Hawkins R.H., Swank W.T., Campbell J.L., Adams M.B., Jack- son R., Tollner E.W., 2012. Runoff Curve Numbers for 10 Small Forested Watersheds in the Mountains of the Eastern United States. Journal of Hydrologic Engineering (ASCE) 17: 1188-1198.

US Army Corps of Engineers, 2002. HEC-GeoHMS 10 for ArcGIS 10.0. Hydrologic Engineering Center, Davis, California.

Vojtek M., 2014. Estimation of N-Year Maximum Discharges for the Vyčoma Stream (Hájovňa Slače Profile). In: Scientia iuvenis: Book of Scientific Papers. CPU, Nitra: 279-288.

Yu B., 1998. Theoretical justification of SCS-CN method for runoff estimation. Journal of Irrigation Drainage Division (ASCE) 124: 306-310.

Wilcox B.P., Rawls W.J., Brakensiek D.L., Wight J.R., 1990. Predicting runoff from rangeland catchments: A comparison of two models. Water Resources Research 26: 24012410.

Zhan X.Y., Huang M.L., 2004. ArcCN-Runoff: An ArcGIS tool for generating curve number and runoff maps. Environmental Modelling \& Software 19: 875-879. 